\title{
Verification of Process ANd MAChine CAPABILITy For Precision Automotive Production
}

\author{
Simona Dudackova \& Katerina Bicova
}
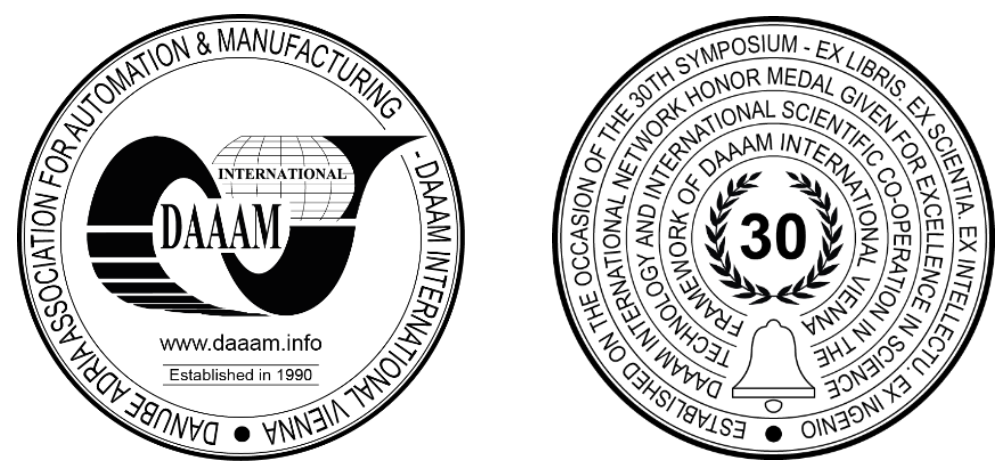

This Publication has to be referred as: Dudackova, S[imona] \& Bicova, K[aterina] (2019). Verification of Process and Machine Capability for Precision Automotive Production, Proceedings of the 30th DAAAM International Symposium, pp.0962-0966, B. Katalinic (Ed.), Published by DAAAM International, ISBN 978-3-902734-22-8, ISSN 1726-9679, Vienna, Austria

DOI: $10.2507 / 30$ th.daaam.proceedings.133

\begin{abstract}
Currently, high demands are placed on the quality of products and services. This paper focuses on the evaluation of the capability of the production process and then the capability of the machine itself in order to verify the suitability of use for the precise production of parts. The analysis is performed on data from serial production of thrust arms for thrust bearings. Requirements for manufacturing precision and associated capability are required by the ISO 9000 series standards, especially IATF 16949 for automotive industry. Selected components are measured at two different locations. Data are recorded and gradually processed into control charts. Subsequently, the machine capability was determined. After evaluating the results, several suggestions have been made to improve the production process and the associated sustainability of the machine.
\end{abstract}

Keywords: Process capability; machine capability; SPC; ISO 9000; IATF 16949.

\section{Introduction}

The current market aims to accelerate production processes and improve the quality of products and services. This is related to the effort to meet the customer's requirements, which continue to grow with the competitiveness and development of modern technologies. All of these approaches seek to support the ISO 9000 series standards. ISO 9001 requirements focus on product quality, manufacturing process capability, high quality service and product delivery to customers. For the automotive field, IATF 16949 extends these requirements, on which both the appropriate use of statistical methods and the maintenance of the manufacturing process capability are based. [1]

In this paper we focused on eligibility because the eligibility of the process is an important aspect of quality production. The main idea for the subsequent study is that the eligible process can only take place at a production facility that is proven to be competent. [2]

The aim is therefore to propose a procedure for short-term examination of machine capability so that it can offer customers a consistently high-quality product at economically comparable costs. 


\section{Analysis of production data}

In this study, we used data from the series production of rocker arms that are part of the thrust bearing (see the figure of the part with the critical dimension marked). It is a part where not only high dimensional accuracy is required but also the constant capability of the production process. The manufacturing process is subject to the requirements of IATF 16949.
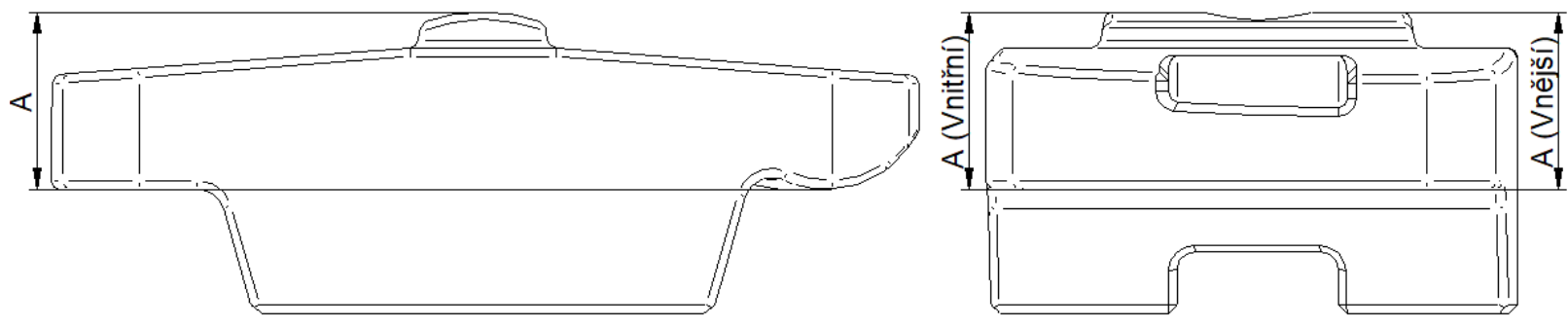

Fig. 1. Component model

\section{1. $S P C / R D$}

For the initial analysis of the measured data, a control diagram was chosen. The control chart is one of the seven basic quality control tools. This is a graphical method that is used to show changes in the process. The diagram consists of a central control line (CL) and two control limits - upper (UCL) and lower (LCL). The central control line expresses the average value of the selected characteristic. The regulatory limits are determined by the variability of random causes. If we assume that there are only random causes, the measured values will most likely lie within the regulatory limits.

SPC is a tool that can be used to monitor the stability of given system over the long term as well as whether the monitored process behaves as expected. It can be assessed whether the variability of the parameter is due to accidental fluctuations or specific causes. Use is possible wherever a given parameter is gradually monitored over time. [3], [4]

Precise manufacturing, especially in the automotive field, requires reliable technology with high and verifiable repeatability. Thanks to RD we can get an idea whether it is a statically manageable process. This is a statically manageable process if it is only affected by random causes. These are unidentifiable causes that can be taken as a natural feature of the process. They are permanent and relatively predictable. They can only be reduced by a radical change in production. If there are any fluctuations / trends in the process, it indicates that these are definable causes of variability. These are divided into unpredictable and predictable. The unpredictable definable causes are undesirable and should be eliminated. The predictable causes that can be predicted are due to the nature of process and can be reduced to some extent (eg tool blunting in machining).

Currently, 25 rocker arms are measured. Each rocker arm was measured at two different locations (internal and external) using a dial gauge with an accuracy of 0.01 . The rocker arm tolerance is $14_{0}^{0,03}$. The measured data are shown in table 1 , followed by a pair of control charts for mean and span. Basic values are set.

\begin{tabular}{|c|c|c|c|c|c|}
\hline Part & \multicolumn{2}{|c|}{ Real dimension } & Part & \multicolumn{2}{c|}{ Real dimension } \\
\hline \multirow{2}{*}{1} & A external & 0.02 & \multirow{2}{*}{14} & A external & 0 \\
\cline { 2 - 3 } & A internal & 0.02 & & A internal & 0 \\
\hline \multirow{2}{*}{2} & A external & 0.01 & \multirow{2}{*}{15} & A external & 0.01 \\
\cline { 2 - 3 } & A internal & 0.01 & & A internal & 0.01 \\
\hline \multirow{2}{*}{3} & A external & 0.02 & \multirow{2}{*}{16} & A external & 0.01 \\
\cline { 2 - 3 } & A internal & 0.02 & & A internal & 0.01 \\
\hline \multirow{2}{*}{4} & A external & 0.02 & \multirow{2}{*}{17} & A external & 0.01 \\
\cline { 2 - 3 } \cline { 5 - 6 } & A internal & 0.02 & & A internal & 0.01 \\
\hline \multirow{2}{*}{5} & A external & 0.01 & \multirow{2}{*}{18} & A external & 0.02 \\
\cline { 2 - 3 } & A internal & 0.01 & & A internal & 0.02 \\
\hline \multirow{2}{*}{6} & A external & 0.01 & \multirow{2}{*}{19} & A external & 0.02 \\
\cline { 2 - 3 } & A internal & 0.01 & & A internal & 0.02 \\
\hline \multirow{2}{*}{7} & A external & 0.01 & \multirow{2}{*}{20} & A external & 0.02 \\
\cline { 2 - 3 } \cline { 5 - 6 } & A internal & 0.01 & & A internal & 0.02 \\
\hline
\end{tabular}




\begin{tabular}{|c|c|c|c|c|c|}
\hline \multirow{2}{*}{8} & A external & 0.01 & \multirow{2}{*}{21} & A external & 0.02 \\
\cline { 2 - 3 } \cline { 5 - 5 } & A internal & 0.01 & & A internal & 0.02 \\
\hline \multirow{2}{*}{9} & A external & 0.02 & \multirow{2}{*}{22} & A external & 0.02 \\
\cline { 2 - 3 } \cline { 5 - 6 } & A internal & 0.02 & & A internal & 0.02 \\
\hline \multirow{2}{*}{10} & A external & 0.01 & \multirow{2}{*}{23} & A external & 0.01 \\
\cline { 2 - 3 } & A internal & 0.01 & & A internal & 0.01 \\
\hline \multirow{2}{*}{11} & A external & 0.01 & \multirow{2}{*}{24} & A external & 0.01 \\
\cline { 2 - 3 } & A internal & 0.01 & & A internal & 0.01 \\
\hline \multirow{2}{*}{12} & A external & 0.01 & \multirow{2}{*}{25} & A external & 0.01 \\
\cline { 2 - 3 } & A internal & 0.01 & & A internal & 0.01 \\
\hline \multirow{2}{*}{13} & A external & 0.015 & & & \\
\cline { 2 - 3 } & A internal & 0.015 & & & \\
\hline
\end{tabular}

Table 1. Measured data

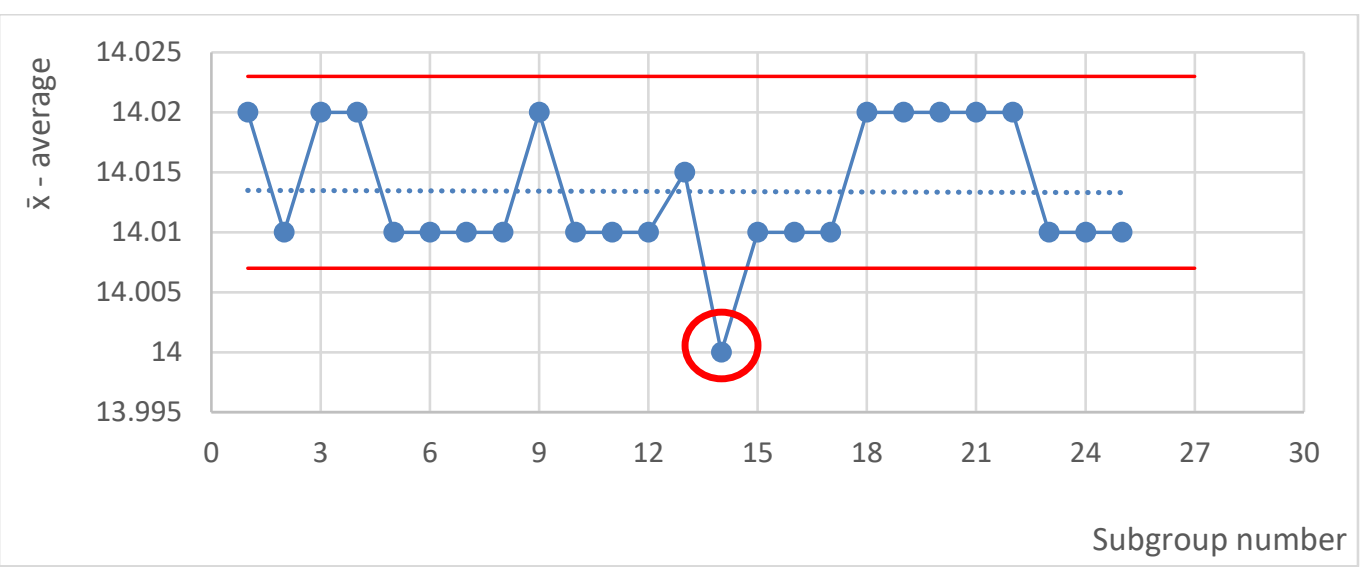

Fig. 2. Graph for average

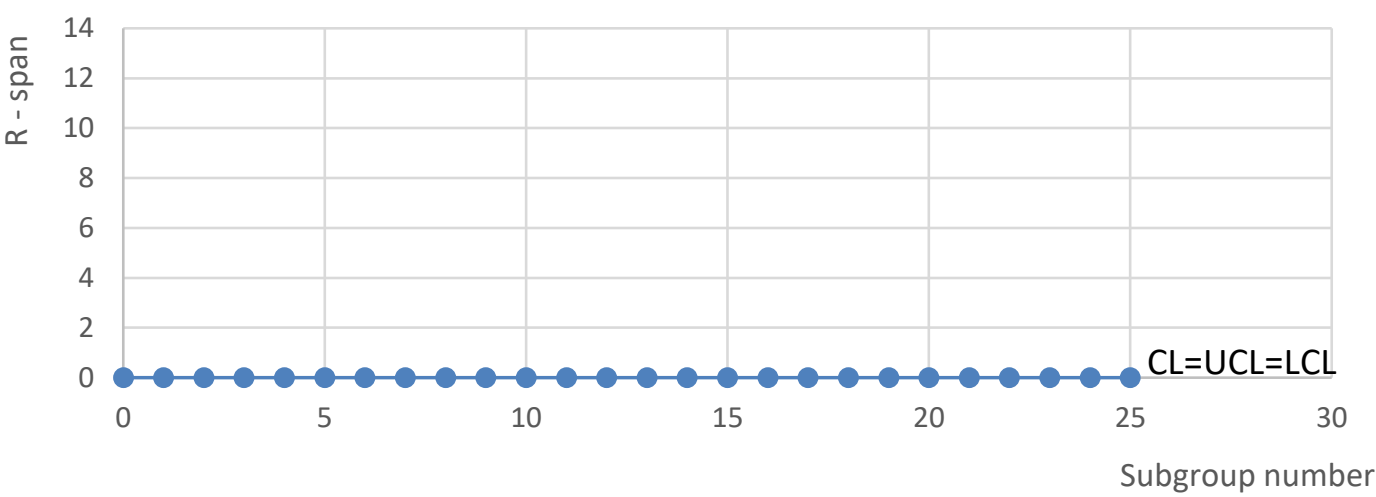

Fig. 3. Graph for span

As can be seen from the diameter diagram (fig. 2), value 14 is below the lower tolerance limit. This situation has been investigated and since this was not a particular cause of the fluctuation and the relevant components are in order from customer's perspective, the process is declared stable despite this situation.

In the span diagram (fig. 3), the values are the same in all cases so the span is zero and the values of the tolerance limits are also equal to UCL and $\mathrm{LCL}=\mathrm{CL}=0$. It can be caused an insufficient number of measured data on individual rocker arms. It is therefore possible to choose a different method of evaluation or to use a more accurate measuring tool than the dial indicator or data acquisition. 


\subsection{Process and machine capability}

The next step of the analysis is to determine the process capability and then the production equipment. In our case, it is a universal turning centre DMU 40 eVo linear with a load capacity of up to $250 \mathrm{~kg}$ and speeds in the C axis of up to $1200 \mathrm{rpm}$. The motor spindle has a speed of up to $18000 \mathrm{rpm}$ and a torque of $130 \mathrm{Nm}$. [6]

The $c_{p}$ index is most often used to determine process capability. For the index: $c_{p}=\frac{U S L-L S L}{6 \sigma}$, where USL indicates the upper tolerance in the drawing and LSL the lower tolerance. It is therefore the share between the tolerance field and the production range. To assess the process capability, the conditions of a statically mastered process must be met, which has been verified by means of control charts and the monitored values must correspond to the Gaussian distribution (verification eg by histogram). In the automotive industry, a process is considered eligible if it is an index $c_{p}>1.67$.

Machine indexes are not defined in any ISO. Every company has set its own rules. For this analysis were chosen relationships from Ford $-c_{M}, c_{M K}$.

$$
\begin{aligned}
& C_{M}=\frac{3 / 4\left(T_{H}-T_{D}\right)}{6 S^{M}}=\frac{T_{H}-T_{D}}{8 S^{M}} \\
& C_{M K}=\min \left(C_{M K U}, C_{M K L}\right) \\
& C_{M K U}=\frac{3 / 4\left(T_{H}-\bar{x}^{M}\right)}{3 S^{M}}=\frac{T_{H}-\bar{x}^{M}}{4 S^{M}} \\
& C_{M K L}=\frac{3 / 4\left(\bar{x}^{M}-T_{D}\right)}{3 S^{M}}=\frac{\bar{x}^{M}-T_{D}}{4 S^{M}}
\end{aligned}
$$

After substituting into the process capability formula (1), we get $c_{p}=1.33$, ie. that process capability is currently based on process $c_{p}>1$. Because it is automotive industry where $c_{p}=1.67$ is required. Therefore, we will have to verify the results with a more accurate gauge to obtain more accurate data to achieve the desired $c_{p}$ or tighten production requirements. Whether the values are satisfactory or not is explained in the following figure where Sigma rule 6 is shown indicating ppm for each strip.

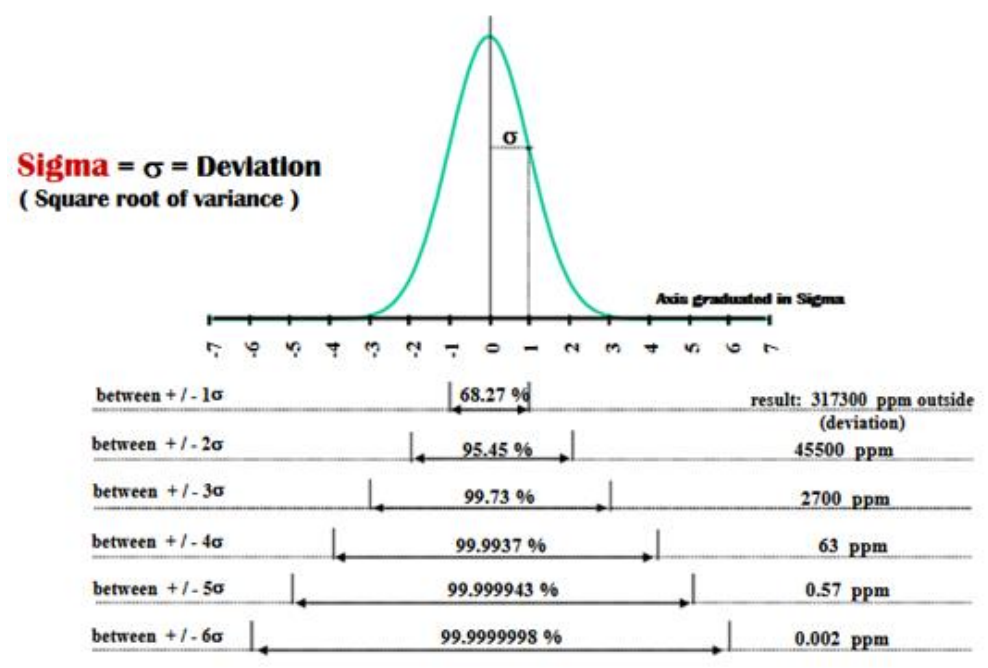

Fig. 4. Six Sigma principle [7]

Since the current process capability reliability is $c_{p}=1$, reliability is currently considered to be $99.73 \%$, which corresponds to an interval of $\pm 3 \mathrm{~s}$.

After substituting into the formula (2) for machine capability, the result was $c_{M}=0.91$. Because higher manufacturing accuracy is required, the results must be measured with a more accurate gauge and then the machine capability can be calculated with an interval of $\pm 4 \mathrm{~s}$ for more accurate production. 


\section{Summary of results}

After an overall analysis of the available data, we came to the conclusion that more data on individual rocker arms was needed to test the machine's capability. Especially, to find out the span in the individual subgroups, which is necessary to produce a control chart for the span. In our case, there was a range of 0 in each subgroup from which we cannot clearly confirm whether this is a stable process or not.

In the case of capability, the capability of the process is currently $c_{p}=1$, which is insufficient for the production of parts and data will need to be measured using a more accurate meter; the capability of the machine will then be recalculated.

In addition to the set methodology in the company, other process analysis tools can also be used to monitor and evaluate the production process. It is always necessary to choose appropriate indicators and collect relevant data. This is important for the security requirements of reliability and suitability of the manufacturing process. Besides the use of histograms, process capability and control charts, there are of course other statistical methods, which are requested by standards. [8], [9]

\section{Conclusion}

The main idea in this paper is that a process capability can only take place on a production capability that is proven to be competent. The aim was therefore to propose a procedure for short-term fitness testing to offer customers a consistently high-quality product at economically comparable costs.

An analysis based on the available data, we concluded that the examination of capability for the machine is required to measure more data.

The difficulty in assessing the capability of production machines based on capability testing is the number of influencing factors outside the machine itself, which worsen the assay result. In addition to equipment, these factors can also influence the quality of products and services.

Therefore, further studies are possible with a focus on the influence of individual factors on the machine capability and the associated overall capability of the production process. If we focus only on manufacturing equipment, we can consider reliability studies or reliability assessment methods.

\section{Acknowledgments}

This article was created under the project SGS-2019-008: Research and Development for Innovation in the Field of Manufacturing Technology - Machining Technology III.

\section{References}

[1] Standard for quality management system in the automotive industry IATF 16949:2016. (2016). Prague: ČSJ

[2] Culka, P. a kolektiv (2016). Management jakosti v automobilovém průmyslu: Zabezpečování jakosti před sériovou výrobou. 2. přeprac. vyd. Praha: Česká společnost pro jakost, 1996. 136 s. ISBN 80-02-01187-2.

[3] Tabak, John (2004). Probability and statistics: The science of uncertainty. New York : Fact On File, Inc., 2004. ISBN: 0-8160-4956-4.

[4] ČSN ISO 8258 (1998) Shewhartovy regulační diagramy. (Shewharts control charts) Praha : Český normalizační institut, 1998.

[5] Ljungblad, U.: Statistical process control applied to additive manufacturing enables series production of orthopedic implants (2010) Annals of DAAAM and Proceedings of the International DAAAM Symposium, pp. 1569-1570. https://www.scopus.com/inward/record.uri?eid=2-s2.084904431140\&partnerID=40\&md5=b1991c7ab3e12a189122e7bc0a9691d0

[6] DMG MORI (2019): CNC obráběcí stroje, kovoobráběcí stroje DMG MORI at: https://cz.dmgmori.com/produkty/stroje/frezovani/petiose-frezovani/dmu-evo/dmu-40-evo-linear, date cited: 0830-2019

[7] Lupienski, J.A.(2019): Six sigma [online].[cit. 2019-08-19]. Dostupné z https://slideplayer.com/slide/4971324/

[8] Bícová, K., a Bebr, L. (2018). Analysis and dependability of production processes for the automotive industry. Paper presented at the Annals of DAAAM and Proceedings of the International DAAAM Symposium, 416-420.

[9] Tent, I.-D., Dumitrescu, C.-D., Trandafir, N. (2010) Statistical quality control methods of products and services. Paper presented at the Annals of DAAAM and Proceedings of the International DAAAM Symposium 2010, Pages 1341-1342 